\title{
Ayurveda Insights on Physiology of Sweating and Thermoregulation
}

\author{
Vandana Verma*, Sangeeta Gehlot and Sonam Agrawal \\ Department of Kriya Sharir, Faculty of Ayurveda, Institute of Medical Sciences, Banaras Hindu \\ University, Varanasi - 221005, Uttar Pradesh, India; vanadana.verma04@gmail.com, \\ sangeetagehlot@gmail.com, cutesonam.agrawal@gmail.com
}

\begin{abstract}
Physiology of sweating and thermoregulation was well conceived by Ancient Ayurveda scholars. The detailed description of Svedavaha Srotas (channels carrying sweat), Sveda (sweat) as Mala (waste), its mechanism of formation on exposure to heat, therapeutic application of heat for inducing sweating under the concept of Svedan Karma (sudation) for purification and balancing the Dosha for management of disorders reflects the deep understanding of Ayurveda scholars about the physiology of sweating and temperature regulation. Keeping these facts in mind a detailed review has been done as an attempt to understand the physiology of sweating and temperature regulation mechanism described in Ayurveda in view of contemporary sciences and recent researches.
\end{abstract}

Keywords: Dosha, Mala, Swedan (sudation), Temperature Regulation

\section{Introduction}

The fundamental concept of human physiology in Ayurveda revolves around the concept of Dosha, Dhatu and Mala. These three have been considered as root for the sustenance and homeostasis of the body ${ }^{1}$ since the balanced functional state of these three components is important for various functions as well as origin, development and progression of life.

Among these, Dosha are the biological entity governing and regulating all the physiological functions of the body, Dhatu are the major tissues of the body while Mala refers to the excretory products of the digestion and metabolism. But Acharya Charak has given more comprehensive understanding about Mala i.e. any factor which produces hindrance in the normal physiological functions or causes deterioration or pain in the body is considered as Mala. It includes aggravated Dosha i.e. Vata, Pitta and Kapha, Dhatu (tissues), or Mala (the waste products of metabolism, which get stuck to the orifices of the body, of various forms and are in process of being removed from the body $)^{2}$. All the vitiated Dosha, Dhatu are said to be Mala and considered as the primary factor in causation of all diseases ${ }^{3}$. All these Mala can be classified into two types i.e. Aahara Mala and Dhatu Mala. Aahara Mala are Mutra (urine), Purisha (feces) and Sveda (sweat) ${ }^{4}$ while Dhatu Mala are Kapha, Pitta, Khamala, Sveda, Keshaloma, Sneha of eyes and skin for Rasadi Dhatu respectively ${ }^{5}$. Detailed descriptions are available regarding the physiological functions and features of hypo and hyper functional state of Mutra (urine), Purisha (feces) and Sveda (sweat). Sveda is carried away via Svedavaha Srotas, plays an important role in excretion of waste metabolites produced during digestion and metabolism and temperature regulation along with Pitta.

\section{Material and Methods}

A comprehensive study was done on description related to physiological functions of Sveda, features of its Kshaya and Vriddhi, Sveda carrying channels, physiology

\section{${ }^{*}$ Author for correspondence}


of sweat secretion, causes of vitiation of Svedavaha Srotas, features of vitiated Svedavaha Srotas and their management. Relevant matters were also collected from online resources like Google scholar, Medline plus, PubMed health and central etc.

\section{Review and Discussion}

\subsection{Sveda (Sweat)}

Sweat is a fraction of Udaka (water) that comes out of Lomakoop (skin pores/hair follicles) on exposure to heat ${ }^{6}$. Sveda has been considered as Mala of both Aahara and Meda Dhatu ${ }^{7}$, as it is formed during digestion and metabolism. It has been also considered as Upa Dhatu of Meda Dhatu ${ }^{8}$. Sweat is carried by Svedavaha Srotas and the Moola of Svedavaha Srotas is Lomakoopa and Meda9.

\subsection{Formation of Sveda and Temperature Regulation on Exposure to Heat}

Sveda is formed of Udaka which comes out through Lomakupa (hair follicles) which is the Moola of Svedavaha Srotas, when it gets combined with Ushma (heat) ${ }^{6}$. This description regarding Sveda by the great physician Charak shows his understanding about the formation of sweat, that when body gets exposed to heat, in adaptive response there is sweating to lower down the body temperature. Sveda shares Aashraya Aashrayi relationship with Pitta Dosha ${ }^{10}$ and has been considered as one of the important dwelling site of Pitta Dosha along with Rakta (blood) ${ }^{11}$. Pitta Dosha is responsible for all kind of transformations i.e. digestion and metabolism resulting in heat production. Thus, the body Ushma (heat) depends upon the functional state of Pitta Dosha ${ }^{12}$. During the process of sweating there is loss of body Ushma (heat) along with sweat because of Aashraya Aashrayi (abode-content) relationship with Pitta Dosha ${ }^{10}$. Sveda is helpful in maintenance of body temperature along with Pitta. Svedavaha Srotas is the functional site of Samana and Vyana Vata hence sweat secretion is regulated by Samana and Vyana Vata ${ }^{13,14}$. The regulation of sweating by Samana and Vyana Vata can be understood as autonomic nervous regulation of sweating and temperature.
Moreover, it is well understood that quantity of sweat secreted, depends upon the level of hydration and metabolism of the body. It is also well understood from the contemporary literature that sweat loss is one of the main mechanism regulating the temperature of the body ${ }^{15}$. Sweat controls body temperature, cools the body, purifies the blood etc. Thus, Sveda formation described by Ayurveda scholars physiologically simulates with sweating mechanism of contemporary literature.

\subsection{Sweat Carrying Vessels: Description of Arterial and Venous Network of Skin in Relation to Sweat Formation}

Sushruta has described about the arterial and venous network of skin in relation to sweat formation in skin under the description of Triyaga Dhamani ${ }^{16}$ (blood vessels placed diagonally). Each one of four oblique or transverse Dhamani (blood vessels) gets further divided into hundreds and thousands of branches and finally becomes innumerable so that the entire body is covered like network, bound and pervaded; their openings are attached to the hair follicles ${ }^{16}$. These purvey Sveda (sweat to the exterior) and replenish Rasa both inside and outside. Through these vascular networks, only the active fraction of medicament applied in the form of massage, bath or paste enters into the body after being transformed in skin. They are also responsible for the perception of sensation of the touch both comfortable and uncomfortable ${ }^{16}$. Sushruta has described that Rakta (blood) is responsible for touch sensation or perception of stimulus along with Vata Dosha ${ }^{17}$.

These are also the path for the manifestation of vitiated Dosh ${ }^{18}$. This description might be indicating the broad capillary network of the body which regulates permeation of fluid, secretion of sweat through vasodilatation and vasoconstriction and carrying touch impulses through regulating the proper blood flow (Figure 1).

\subsection{Temperature Regulation on Exposure to Cold}

In Shishir Ritucharya (winter season regimen), they have discussed that the exposure of cold leads to Vatavriddhi which causes the closure of body pores (Romakoopavrodha) thus prevents the external heat loss and the heat gets internalized resulting the augmentation 


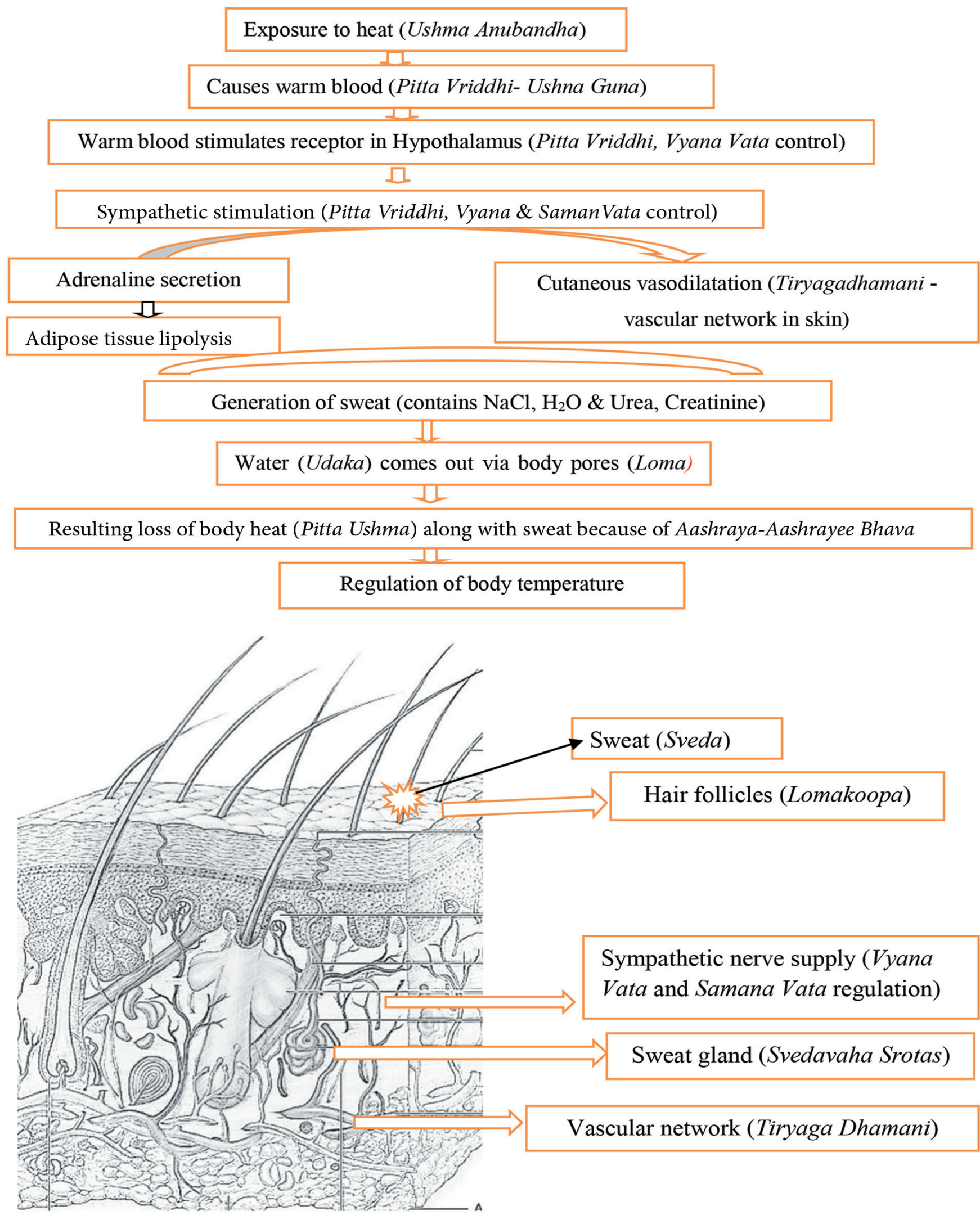

Figure 1. Schematic representation of mechanism of sweating and temperature regulation on exposure to heat, described in Ayurveda, in view of modern physiology. 
of Agni (power of digestion and metabolism) in winter season ${ }^{19,20}$. This description is similar to the contemporary sciences as exposure to cold leads to sympathetic stimulation causing increased metabolism, heat production and vasoconstriction in skin vascular bed that prevents the heat $\operatorname{loss}^{21}$ (Figure 2).

\section{Factors Affecting Sweat}

- Psychosomatic constitution (Prakriti): Ayurveda has described that the quantity and odor of sweat depends upon psychosomatic constitution of an

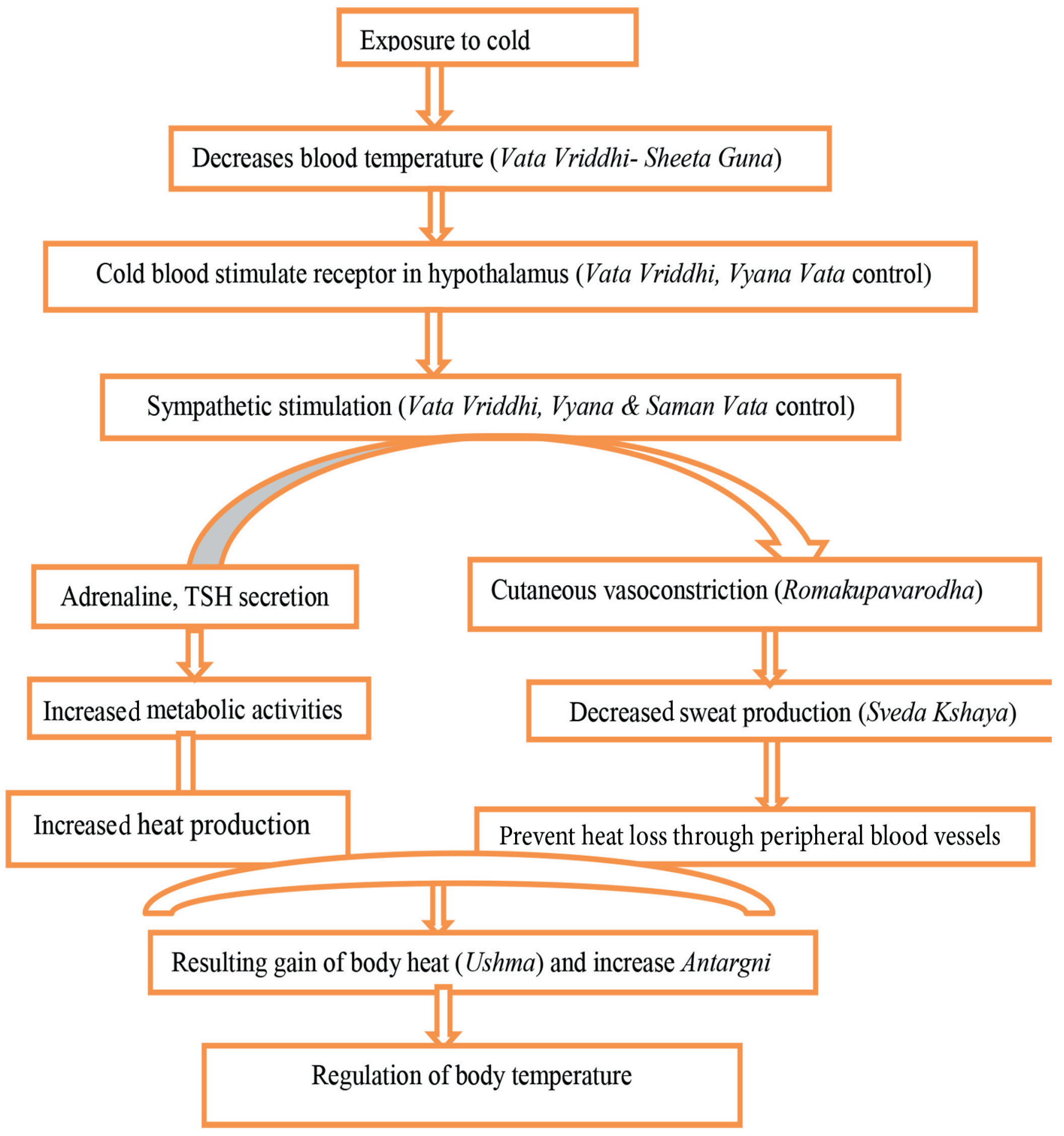

Figure 2. Schematic representation of mechanism of temperature regulation on exposure to cold. 
individual. Since sweat is considered as Mala of Meda Dhatu, there might be a possibility of difference in composition of Sveda as well as rate of sweating in individuals of different constitution. The Pitta Prakriti individuals have profuse sweating with foul smell, it may be due to more Drava, Ushna and Visra properties of Pitta Dosha ${ }^{22}$. The quantity of sweat depends upon the hydration level of the body as it is fraction of Udaka (water) in body, which is ten Anjali ${ }^{6}$. Thus, for temperature regulation appropriate hydration of body is necessary otherwise the temperature regulation mechanism will not be proper. The apocrine secretion of sweat gland depends upon adrenaline hormone. The apocrine gland activity may be more in Pitta Prakriti individuals that leads to foul smelling sweat. Recent research has reported that Pitta Prakriti individuals are fast metabolizers due to higher activity of CYP2C19 gene than in other two Prakriti ${ }^{23}$. Because of more heat production in Pitta Prakriti individuals resulting more sweating and water loss, which causes more thirst and water intake in Pitta Prakriti inherently ${ }^{22}$.

- Emotional States - Bhaya (fear), Krodha (anger), Shoka (grief) ${ }^{24}$ are the negative emotional states that lead to higher sympathetic activity due to aggravated state of Vata and Pitta Dosha resulting in more sweating. Bhaya and Shoka causes aggravation of Vata Dosha while Krodha aggravates Pitta Dosha. Vata and Pitta Dosha are responsible for physiological sweating ${ }^{12,14}$ thus their aggravated state leads to excessive sweating.

- Level of Exercise (Vyayama)- Exercise enhances the Agni resulting in increased metabolic activity and heat production (Ushma) and thus sweating to balance the body heat. Excessive exercise (Ativyayama) has also been considered as one of the factors of Svedavaha Srotodushti ${ }^{24}$.

- Measures to Stimulate Sweating without Application of Heat (Niragnisveda measures) - Measures for Niragnisveda are exercise, residing in a warm chamber, wearing heavy clothing, excessive drinking, fear, anger, wrestling, exposure to sunlight ${ }^{25}$ etc. referring to physiological causes of sweating.

- All these measures of Niragnisveda, emotional states like Bhaya (fear), Krodha (anger), Shoka (grief) and factors discussed under the causes of
Srotodushti of Svedavaha Srotas increase body temperature which stimulates sympathetic nervous system with the release of epinephrine and nor epinephrine that further increase BMR which in turn increases heat production and significantly modulates the core temperature as a response to changing environmental conditions. Thus, the measures for Niragni Sveda described by Ayurveda scholars correspond to adaptive mechanisms of human beings.

- Obesity (Atisthaulya): In obesity due to Medovriddhi, there is excessive sweat formation ${ }^{26}$ since sweat is Mala of Medodhatu. Studies have reported that obesity is associated with increased heat production but the heat loss impedes due to excess deposition of fat in subcutaneous layer resulting in increased thickness of subcutaneous tissue and vasoconstriction in skin because of sympathetic over activity due to autonomic dysregulation ${ }^{27}$, so in obese the major site of heat loss is palm and sole due to presence of arteiovenous anastomoses. Degree of thermal insulation is positively correlated to degree of obesity ${ }^{28}$. Ayurveda has also given similar thought that in obesity there is Vata Vriddhi ( autonomic dysfunction) and Srotoavrodha due to excess deposition of fat resulting in the augmentation of digestive fire and more appetite ${ }^{29}$, more intake of food and thus more formation of Aahara Mala i.e. sweat also. While the heat loss is hampered, results in increased core temperature and hence, more sweating.

- Quantity of Sveda: Quantitative methods (Anjali Pramana) of assessment have been given for the measurement of fluid substances of the body. These measurements pertain to the ideal standards and are subjected to undergo variation in the form of increase or decrease in a normal individual and this can be ascertained by inference. Anjali Pramana of Udaka is 10 Anjali and as Sveda is formed from Udaka, its quantity will vary with the quantity of the Udaka ${ }^{6}$. The amount of secretion of Sveda will depend upon the state of Pitta Dosha and Prakriti of an individual. Hyper functioning of Pitta Dosha will lead to increased secretion of sweat, Pitta Prakriti individuals will have increased secretion of sweat ${ }^{30}$ while Kapha Prakriti ${ }^{31}$ individuals will have decreased quantity of sweat. 
- Composition of Sweat: Sweat mainly consists of water ${ }^{32}$, primary secretion formed by sweat gland is similar to plasma except, it does not contain proteins. It also contains $\mathrm{Na}^{+}, \mathrm{K}^{+}, \mathrm{Cl}^{+}$, urea and lactic acid. The concentration of $\mathrm{K}^{+}$in sweat is 1.2 times of plasma while urea is 2 times of plasma and lactic acid is 4 times of plasma. $\mathrm{pH}$ of sweat is 4.5 to 7.0 ; mineral composition of sweat depends upon various factors of an individual like, their acclimatization to heat, exercise, the particular stress source, the duration of sweating, and the composition of minerals in the body. Fukumoto et al, (1988) in their work found that the chloride concentration of sweat is well related to work intensity and appears to be dependent on thermal stress. Sodium and chloride concentration of sweat are higher after vigorous physical exercise than after exposure to thermal stress. It is not known that whether concentration would be similar in cases of other substances such as creatinine, urea, nitrogen and potassium ${ }^{33}$.

- Functions of Sveda: Chief function of Sveda is to retain moisture in skin and to bestow moistness and softness to the skin ${ }^{34,35}$.

- Hyper and Hypo-secretion of Sveda: Dosha, Dhatu and Mala are subjected to hypo or hyper functioning based on various factors. These symptoms may manifest individually or as symptoms of various diseases. The hyper secretion of Mala can be assessed by observing their increased quantity, heaviness, itching and Kleda (excess moisture) in their Aashraya (reservoir sites), while hypo secretion of Mala can be assessed by observing dryness, pricking pain, emptiness and tightness at their sites, however decrease in Mala is difficult to perceive ${ }^{36,37}$.

- Features of Hyper Secretion of Sveda (Sveda Vriddhi): Excessive sweating gives rise to bad odor of the skin and itching ${ }^{38}$. Hyperhydrosis causes excess moisture over skin leading to bacterial and fungal infection resulting in itching ${ }^{39}$.

- Features of Hypo Secretion of Sveda (Sveda Kshaya): Decrease of Sveda produces stiffness of hair follicles, falling of hairs, dryness and cracking of the skin, abnormalities of touch or loss of sensation (tactile sensation) and absence or scanty sweating ${ }^{40,41}$.

- Physiology of Svedavaha Srotas: Srotas are the inner transport system of the body which provide base for activities of other important bio-factors like three Dosha, the seven Dhatus, Mala, Oja and the Agni etc. Dosha, Dhatu and Mala are dependent on Srotas for their formation, transportation and destruction. The Srotas system plays a key role in physiology including pathophysiology and pharmacophysiology ${ }^{42}$.

- Srotas are of two types i.e. Sthula (Gross) and Anu (minute $)^{43}$. The Anu Srotas are innumerable which refers to cell or its organelle or pores on cell, while Sthula Srotas (major physiological systems) are 13 in numbers ${ }^{44}$ which can be broadly subdivided in three subgroups concerned with ingestion (Prana, Udaka, Anna), Dhatu (Dhatuvaha Srotas) and excretion (Mutra, Purisha, Sveda). Svedavaha Srotas are sweat carrying channels. Svedavaha Srotomoola are Meda (adipose tissue) and Lomakupa (minute pores of the skin located around the base of hair follicles of the skin $)^{9}$. The functional regulation of Svedavaha Srotas is under the control of Vyana Vata and Saman Vata refers to autonomic regulation of sweating.

- Ayurveda scholars have sound understanding of sweating mechanism and its regulation and role in eliminating the Mala (toxins) as well as in maintenance of homeostasis of body. Based on these understandings, they have designed Svedan Karma (sudation therapy) as a therapeutic modality and under the Poorva Karma of Panchakarma (pre procedure to Panchakarma) for purification of the body and therapeutic purposes to subside Vata and Kapha Dosha. Svedavaha Srotas has great role in temperature regulation, protection of body as well as excretory function.

\section{Etiological Factors Causing Vitiation of Svedavaha Srotas}

The factors causing vitiation of Svedavaha Srotas are excessive exercise (Ativyayama), prolonged exposure to excess heat (Atisantaapa), improper intake of cold and hot substances, exposure to sudden cold after exercise (Sheetaushna Upakramasevanaat), excessive anger (Krodha), grief (Shoka), excessive fear (Bhaya) ${ }^{24}$. The causes of vitiation of Svedavaha Srotas mentioned are similar to the causes of secondary hyperhydrosis like alcohol abuse, anxiety, hyperthyroidism, obesity ${ }^{45}$. These 
entire conditions produce imbalance in heat production and heat loss thus altering the sweating. This leads to disturbance in functional state of Svedavaha Srotas.

- Characteristics of Vitiated Svedavaha Srotas: The vitiated Srotas are assessed by observing their functional state. The manifestations of vitiated Svedavaha Srotas are associated with either increased or decreased functioning of Sveda i.e. lack of sweating or excessive sweating (Asvedanam or Atisvedanam), roughness or smoothness of the skin (Parushyamatishlakshnata), burning sensation in body (Paridaha), horripilation (Lomaharsha) ${ }^{9}$.

- Features of Excessive Sweating (Ati-Swedan): Burning sensation in the body, aggravation of Pitta, fainting (Murchha), heaviness of the body, pain in joints, Visphota (blisters), Bhrama (giddiness), Klama (tiredness), vomiting, Trishna (thirst), Rakta Dushti Lakshana (features of vitiated blood) etc. are the features of excessive sweating (Ati-Swedan). The characteristics mentioned in case of Atiswedan are same as in dehydrated state of body due to excess water and mineral loss owing to excessive sweating ${ }^{46}$.

- Disorders in which Svedavaha Srotodushti is found: In Udara Roga, Kushtha (skin disorders), Vatarakta (gout), Jwara ( febrile state of malaria, typhyoid) and Atisthulta (obesity) ${ }^{47-50}$ Svedavaha Srotodushti are found. These conditions have been described under the causes of secondary-hyperhydrosis.

- Management of Vitiated Svedavaha Srotas: 1. The vitiation of Svedavaha Srotas can be managed on lines of treatment of Jwara (fever) ${ }^{51} 2$. Corrective measures advised for excessive sweating are purificatory and palliative. 3. Measures advised for Sveda Kshaya are oil bath (anointing), sudations, physical exercise and use of wine ${ }^{52}$.

- Drugs to Regulate Sweating: Ayurveda scholars have not only described the formation of sweat, its importance in physiological homeostasis, but also described the drugs enhancing the sweating (Svedajanan Dravya) or reducing the sweat formation (Svedopnayana).

- Svedan Drugs: Dravyas which enhance the sweating are called Svedajanan Dravya. In general, the pharmacodynamical properties of Svedan drugs are described as 1) Ushna (Hot), Tikshna (Sharpness),
Sara (Mobility), Snigdha (Unctuousness), Ruksha (Roughness), Sukshma (Subtle), Drava (Liquid), Sthira (Immobility), and Guru (Heaviness) ${ }^{53}$.

- All the below mentioned Dravyas have been indicated in management of various disorders where Svedavaha Srotorodha is found or in general for purification of body.

- Svedajanan: Vatsanabha (Aconitum ferox)

- Svedopag: Shobhanjana (Moringa oleifera), Eranda (Ricinus communis), Arka (Calotropis gigantica), Vrashcheer (white variety of Boerhavia diffusa), Punarnava (red variety of Boerhavia diffusa), Yava (Hordeum vulgare), Tila (Sesamum indicum), Kulattha (Dolichos biflorus), Masha (Phaseolus mungo), Badara (Zizyphus jujuba) $)^{54}$.

- Svedopanayana: Usheera (Vitiveria zizanoidis)

\section{Conclusion}

Review of literature elucidates that Ayurveda has deep insight about the physiology of sweating, sweat formation, its role in temperature regulation and excretoryfunction ofsweat aswell asinbodyhomeostasis. Ayurveda duly acknowledged the applied aspect of Svedavaha Srotas in maintenance of homeostasis of body and in elimination of the Mala (toxins), which has been successfully adopted and designed as the Svedana Chikitsa. Heat applied in Svedana produces heat stress and initiates the thermoregulatory mechanism and produces various haemodynamic changes helping in excretion of metabolic wastes with enhanced immune mechanism. Svedavaha Srotas has great role in temperature regulation, protection of body as well as excretory function.

\section{References}

1. Yadav T. Editor. Reprint ed. Sushruta Samhita of Sushruta with Nibandha Sangraha commentary of Dalhan, Sutrasthana; Doshadhatumalakshayavridhhivigyaniyamadhyaya: Chapter 15, Verse 3. Chaukhambha Sanskrita Sansthana; 2010. p. 67.

2. Sharma RK, Das B. Editors. Reprint ed. Charak Samhita of Agnivesha, volume 2. Sharirasthana; Shariravichayashariram: Chapter 6, Verse 17. Varanasi: Chowkhambha Sanskrita Series office; 2018. p. 438. 
3. Shrikanth KRM. Editor. Reprint ed. Madhavanidana of Madhavakara. Panchanidanalakshanam; Chapter 1, Verse 14. Varanasi: Chaukhambha Orientalia; 2009. p. 5.

4. Sharma RK, Das B. Editors. Reprint Ed. Charak Samhita of Agnivesha, volume 1. Vividhaashitpitiyadhyaya; Sutrasthana: Chapter 28, Verse 4. Varanasi: Chowkhambha Sanskrita Series office; 2018. p. 567.

5. Sharma RK, Das B. Editors. Reprint ed. Charak Samhita of Agnivesha, volume 3. Grahanidoshachikitsitam; Chikitsasthana: Chapter 15, Verse 18-19. Varanasi: Chowkhambha Sanskrita Series office; 2018. p. 15-16.

6. Sharma RK, Das B. Editors. Reprint ed. Charak Samhita of Agnivesha, volume 2. Sharirasthana; Sharirasankhyashariram: Chapter 7 Verse 15. Varanasi: Chowkhambha Sanskrita Series office; 2018. p. 458.

7. Sharma RK, Das B. Editors. Reprint ed. Charak Samhita of Agnivesha, volume 3. Grahanidoshachikitsitam; Chikitsasthana: Chapter 15, Verse 18-20. Varanasi: Chowkhambha Sanskrita Series office; 2018. p. 15-16.

8. Shrikantha KRM. Editor. Reprint ed. Sharangdhara Samhita of Sharangdhara, Purvakhanda: Kalaadikaakhayaana Shariram; Chapter 5, Verse 17 Varanasi: Chaukhambha Orientalia; 2009. p. 22.

9. Sharma RK, Das B. Editors. Reprint ed. Charak Samhita of Agnivesha, volume 2. Srotovimaniyadhyaya; Vimanasthana: Chapter 5 Verse 7-8. Varanasi: Chowkhambha Sanskrita Series office; 2018. p. 174.

10. Shrikantha KRM. Editor. Reprint ed. Ashtanga Hridaya of Vagbhatta, volume 1, Sutrasthana; Doshadivigyaniya adhyaya: Chapter 11, Verse 26. Varanasi: Chowkhambha Krishndas Academy; 2016. p. 160. https://doi.org/10.1071/ PVv2016n183p160

11. Shrikantha KRM. Editor. Reprint ed. Ashtanga Hridaya of Vagbhatta, volume 1, Sutrasthana; Doshabhediya adhyaya: Chapter 12, Verse 2. Varanasi: Chowkhambha Krishndas Academy; 2016. p. 166.

12. Sharma RK, Das B. Editors. Reprint ed. Charak Samhita of Agnivesha, volume 1. Vatakalakaliyamadhyaya; Sutrasthana: Chapter12, Verse 11. Varanasi: Chowkhambha Sanskrita Series office; 2018. p. 240.

13. Sharma RK, Das B. Editors. Reprint Ed. Charak Samhita of Agnivesha, volume 5. Vatavyadhichikitisitam; Chikitsasthana: Chapter 28, Verse 8. Varanasi: Chowkhambha Sanskrita Series office; 2018. p. 21. https://doi.org/10.4102/sajems. v21i1.2938

14. Yadav T. Editors. Reprint Ed. Sushruta Samhita of Sushruta with Nibandha Sangraha commentary of Dalhan, Nidanasthana; Vatavyadhinidanam: Chapter 1, Verse 17. Chaukhambha Sanskrita Sansthana; 2010. p. 67.
15. Sembulingam K. Essentials of medical physiology, sixth edition. New Delhi: Jaypee Brothers Medical Publishers; 2013. p. 361.

16. Yadav T. Editors. Reprint Ed. Sushruta Samhita of Sushruta with Nibandha Sangraha commentary of Dalhan, Sharirasthana; Dhamanivyakaranshariram: Chapter 9, Verse 9 and 7. Chaukhambha Sanskrita Sansthana; 2010. p. 384,385.

17. Yadav T. Editors. Reprint Ed. Sushruta Samhita of Sushruta with Nibandha Sangraha commentary of Dalhan, Sharirasthana; Shiravarna Vibhakti shariram: Chapter 7, Verse 14, Chaukhambha Sanskrita Sansthana; 2010. p. 377.

18. Murthy Shrikantha KR, editor (Reprint edition). Ashtanga Hridaya of Vagbhatta, volume 1, Sutrasthana; Doshadivigyaniyadhyaya: Chapter 11, Verse 35-36. Varanasi: Chowkhambha Krishndas Academy; 2016. p. 163.

19. Sharma RK, Das B. Editors. Reprint Ed. Charak Samhita of Agnivesha, volume 1. Tasyashitiya adhyaya; Sutrasthana: Chapter 6, Verse 9. Varanasi: Chowkhambha Sanskrita Series office; 2018. p. 135.

20. Yadav T. Editors. Reprint Ed. Sushruta Samhita of Sushruta with Nibandha Sangraha commentary of Dalhan, Sutrasthana; Ritucharyaadhyaya: Chapter 6, Verse 11. Chaukhambha Sanskrita Sansthana; 2010. p. 26.

21. Sembulingam K. Essentials of Medical Physiology, sixth edition. New Delhi: Jaypee Brothers Medical Publishers; 2013. p. 345

22. Sharma RK, Das B. Editors. Reprint Ed. Charak Samhita of Agnivesha, volume 2. Rogabhishagjitiyadhyaya; Vimanasthana: Chapter 8, Verse 98. Varanasi: Chowkhambha Sanskrita Series office; 2018. p. 265.

23. Ghodke Y, Joshi K, Patwardhan B. Traditional medicine to modern pharmacogenomics: Ayurveda Prakriti Type and CYP2C19 Gene Polymorphism Associated with the Metabolic Variability. Evid Based Complement Alternat Med. 2011. https://doi.org/10.1093/ecam/nep206. PMid:20015960. PMCid:PMC3135904.

24. Sharma RK, Das B. Editors. Reprint Ed. Charak Samhita of Agnivesha, volume 2. Srotovimaniyadhyaya; Vimanasthana: Chapter 5 Verse 22. Varanasi: Chowkhambha Sanskrita Series office; 2018. p. 178.

25. Sharma RK, Das B. Editors. Reprint Ed. Charak Samhita of Agnivesha, volume1.Svedaadhyaya; Sutrasthana: Chapter14, Verse65.Varanasi: Chowkhambha Sanskrita Series office; 2018. p. 284.

26. Sharma RK, Das B. Editors. Reprint Ed. Charak Samhita of Agnivesha, volume 1. Ashtaninditiyadhyaya; Sutrasthana, Chapter 21, Verse 4. Varanasi: Chowkhambha Sanskrita Series office; 2018. p. 375.

27. Karason K, Molgaard H, Wikstrand J, Sjostrom L. Heart rate variability in obesity and the effect of weight loss. The 
American Journal of Cardiology. 1999; 83(8):1242-7. https:// doi.org/10.1016/S0002-9149(99)00066-1

28. Neves EB, Moreira TR, Lemos RJ, Vilaça-Alves J, Rosa C, Reis VM. The influence of subcutaneous fat in the skin temperature variation rate during exercise. Research on Biomedical Engineering. 2015; 31(4):307-12. https://doi. org/10.1590/2446-4740.0805

29. Sharma RK, Das B. Editors. Reprint Ed. Charak Samhita of Agnivesha, volume 1.Ashtaninditiyadhyaya; Sutrasthana, Chapter 21, Verses 6, 7, 9. Varanasi: Chowkhambha Sanskrita Series office; 2018. p. 375-6. https://doi.org/10.32553/jbpr. v7i6.568

30. Sharma RK, Das B. Editors. Reprint Ed. Charak Samhita of Agnivesha, volume 2. Rogabhishagjitiyadhyaya; Vimanasthana: Chapter 8, Verse 97. Varanasi: Chowkhambha Sanskrita Series office; 2018. p. 264.

31. Sharma RK, Das B. Editors. Reprint Ed. Charak Samhita of Agnivesha, volume 2. Rogabhishagjitiyadhyaya; Vimanasthana: Chapter 8, Verse 96. Varanasi: Chowkhambha Sanskrita Series office; 2018. p. 263.

32. Yadav T. Editors. Reprint Ed. Sushruta Samhita of Sushruta withNibandhaSangraha commentaryofDalhan,Sutrasthana; Doshadhatumalakshayavriddhivigyaniyamadhyaya: Chapter 15, Verse 8. Chaukhambha Sanskrita Sansthana; 2010. p. 67.

33. Fukumoto T, Tanaka T, Fujioka H, Yoshihara S, Ochi T, Kuroiwa A. Differences in composition of sweat induced by thermal exposure and by running exercise. Clinical Cardiology. 1988; 11:707-9. https://doi.org/10.1002/ clc.4960111010. PMid:3224454

34. Shrikantha KRM. Editors. Reprint Ed. Ashtanga Hridaya of Vagbhatta, volume 1, Sutrasthana; Doshadivigyaniyadhyaya: Chapter 11, Verse 5. Varanasi: Chowkhambha Krishndas Academy; 2016. p. 155.

35. Yadav T. Editors. Reprint Ed. Sushruta Samhita of Sushruta with Nibandha Sangraha commentary of Dalhan, Sutrasthana; Doshadhatumalakshayavridhhivigyaniyamadhyaya: Chapter 15, Verse 3(2). Chaukhambha Sanskrita Sansthana; 2010. p. 68

36. Shrikantha KRM. Editors. Reprint Ed. Ashtanga Hridaya of Vagbhatta, volume 1, Sutrasthana; Doshadivigyaniyadhyaya: Chapter 11, Verse 23-25. Varanasi: Chowkhambha Krishndas Academy; 2016. p. 155.

37. Shrikantha KRM. Editors. Reprint Ed. Ashtanga Sangraha of Vagbhatta, volume 1, Sutrasthana; Doshadivigyaniyadhyaya: Chapter 19, Verse 7. Varanasi: Chowkhambha Krishndas Academy; 2017. p. 355.

38. Shrikantha KRM. Editors. Reprint Ed. Ashtanga Hridaya of Vagbhatta, volume 1, Sutrasthana; Doshadivigyaniyadhyaya:
Chapter 11, Verse 14. Varanasi: Chowkhambha Krishndas Academy; 2016. p. 158.

39. Kamudoni P, Mueller B, Halford J, Schouveller A, Stacey B, Salek MS. The impact of hyperhidrosis on patients' daily life and quality of life: a qualitative investigation. Health Qual Life Outcomes. 2017; 15(1):121. https://doi.org/10.1186/ s12955-017-0693-x. PMid:28595584. PMCid:PMC5465471

40. Yadav T. Editors. Reprint Ed. Sushruta Samhita of Sushruta withNibandhaSangrahacommentaryofDalhan,Sutrasthana; Doshadhatumalakshayavridhhivigyaniyamadhyaya: Chapter 15, Verse 17. Chaukhambha Sanskrita Sansthana; 2010. p. 70.

41. Shrikantha KRM. Editors. Reprint Ed. Ashtanga Sangraha of Vagbhatta, volume 1, Sutrasthana; Doshadivigyaniyadhyaya: Chapter 19, Verse 6. Varanasi: Chowkhambha Krishndas Academy, 2017; 354.

42. Verma V. Gehlot S., Review on concept of Srotas. International Journal of Research in Ayurveda and Pharmacy. 2014 MarApr; 5(2). https://doi.org/10.7897/2277-4343.05246

43. Sharma RK, Das B. Editors. Reprint Ed. Charak Samhita of Agnivesha, volume1.Vatakalakaliyamadhyaya; Sutrasthana: Chapter12, Verse 7. Varanasi: Chowkhambha Sanskrita Series office; 2018. p. 237

44. Sharma RK, Das B. Editors. Reprint Ed. Charak Samhita of Agnivesha, volume 2. Srotovimaniyadhyaya; Vimanasthana: Chapter 5 Verse 6. Varanasi: Chowkhambha Sanskrita Series office; 2018. p. 176.

45. Schlereth T, Dieterich M, Birklein F. Hyperhidrosiscauses and treatment of enhanced sweating. Deutsches Ärzteblatt International. 2009 Jan; 106(3): 32-7. https:// doi.org/10.3238/arztebl.2009.0032. PMid:19564960. PMCid:PMC2695293.

46. Sharma RK, Das B. Editors. Reprint Ed. Charak Samhita of Agnivesha, volume 1. Svedaadhyaya; Sutrasthana, Chapter 14, Verse 14-15. Varanasi: Chowkhambha Sanskrita Series office; 2018. p. 271.

47. Sharma RK, Das B. Editors. Reprint Ed. Charak Samhita of Agnivesha, volume 3. Kushthachikitsitam; Chikitsasthana: Chapter 7, Verse 12. Varanasi: Chowkhambha Sanskrita Series office; 2018. p. 321.

48. Sharma RK, Das B. Editors. Reprint Ed. Charak Samhita of Agnivesha, volume 3. Udarachikitsitam; Chikitsasthana: Chapter 13, Verse 20. Varanasi: Chowkhambha Sanskrita Series office; 2018. p. 524.

49. Sharma RK, Das B. Editors. Reprint Ed. Charak Samhita of Agnivesha, volume 5. Vatashonitachikitsitam; Chikitsasthana: Chapter 29, Verse 16. Varanasi: Chowkhambha Sanskrita Series office; 2018. p. 91.

50. Sharma RK, Das B. Editors. Reprint Ed. Charak Samhita of Agnivesha, volume 4. Atisarachikitsitam; Chikitsasthana: 
Chapter 19, Verse 16. Varanasi: Chowkhambha Sanskrita Series office; 2018. p. 217.

51. Sharma RK, Das B. Editors. Reprint Ed. Charak Samhita of Agnivesha, volume 2. Srotovimaniyadhyaya; Vimanasthana: Chapter 5 Verse 28. Varanasi: Chowkhambha Sanskrita Series office; 2018. p. 163.

52. Murthy Shrikantha KR, editor (Reprint edition). Ashtanga Hridaya of Vagbhatta, volume 1, Sutrasthana; Doshadivigyaniyadhyaya: Chapter 11, Verse 35. Varanasi: Chowkhambha Krishndas Academy; 2016. p. 163.
53. Sharma RK, Das B. Editors. Reprint Ed. Charak Samhita of Agnivesha, volume 1. Langhanabrihaniyaadhyaya; Sutrasthana, Chapter 22, Verse 16. Varanasi: Chowkhambha Sanskrita Series office; 2018. p. 388.

54. Sharma RK, Das B. Editors. Reprint Ed. Charak Samhita of Agnivesha, volume 1. Sutrasthan; Shadvirechanashitiyaadhyaya adhyaya Chapter 4 Verse 21, Varanasi: Chowkhambha Sanskrita Series office; 2018. p. 22 